\title{
A COISIFICAÇÃO DO HUMANO EM OBJECTO QUASE, DE JOSÉ
}

\section{SARAMAGO}

\author{
Tiago Barbosa Souza ${ }^{1}$ \\ Francisca Carolina Lima da Silva ${ }^{2}$ \\ Paulo Henrique Passos de Castro ${ }^{3}$
}

\section{Resumo}

Este artigo analisa contos do livro Objecto quase, de José Saramago, com ênfase em "Embargo" e "Coisas", ressaltando a desumanização e a coisificação dos personagens. Esse processo denuncia um dos mecanismos de dominação típicos de regimes totalitários, a colaboração voluntária dos dominados, além de chamar atenção para o aguçado materialismo das relações sociais no ocidente desde a época de publicação da coletânea (1978) até hoje.

\section{Palavras-chave}

Objecto quase. José Saramago. Narrador. Coisificação. Desumanização.

\section{1) Introdução}

José Saramago traz em seu espírito de escritor e de cidadão uma preocupação latente com os rumos de seu país, uma vez que se fez engajado em alguns movimentos políticos ocorridos em Portugal, assim como procurou refletir, através de sua obra literária e jornalística, a configuração histórica e contemporânea de sua terra natal. Porém, faz-se necessário destacar que o patriotismo de Saramago não se configura como um ufanismo utópico, pois o autor não idealiza Portugal, assim como não o faz em relação a nada que traz como tema de seus escritos.

Os textos do autor configuram-se como espécies de manuais de comportamento humano, pois trazem representados todos os tipos humanos, dialogando com a preocupação acerca da atividade e da conduta corruptiva da humanidade, recorrente em sua obra. $\mathrm{O}$ autor se apresenta cético e, por vezes, até pessimista em relação ao rumo que o homem deu ao mundo, o que parece ser influência de todas as fantasmagorias ideológicas e de todo o egocentrismo que a era capitalista instaurou.

Muitas dessas reflexões são construídas a partir de temas relacionados a Portugal, tendo em vista o autor ser declaradamente contra o governo ditatorial instaurado em seu

\footnotetext{
${ }^{1}$ Professor da Universidade Federal do Piauí, doutorando do Programa de Pós-graduação em Letras da Universidade Federal do Ceará.

${ }^{2}$ Professora da Universidade Regional do Cariri, doutoranda do Programa de Pós-graduação em Letras da Universidade Federal do Ceará.

${ }^{3}$ Mestrando do Programa de Pós-graduação em Letras da Universidade Federal do Ceará.
} 
país por Oliveira Salazar em 1933 e deposto apenas em 1974, com a Revolução dos Cravos. A situação imposta aos intelectuais durante esse período fez emergir um sentimento de revolta e o desejo de libertação, materializado em suas obras nas mais variadas perspectivas,

desde a menção a figuras, a fatos diretamente ligados ao salazarismo, à repressão política, ao mundo das prisões e interrogatórios, passando por sua manifestação no mundo estagnado, no qual se procura manter o status quo do domínio dos poderosos sobre os deserdados da sorte, até na sua referência mais subterrânea de um mundo arcaico, reacionário, mantido às custas de um propositado processo de negação do progresso ou mesmo de fixação de formas esclerosadas de educação e planejamento educacional. (GOMES, 1993, p. 86)

Partindo do sentido mais estrito ao mais amplo da opressão, a literatura, além de proporcionar um mergulho em seu universo ficcional, termina por registrar e propor uma nova forma não só de denunciar a situação imposta pela ditadura, como também de trazer ao centro da discussão um discurso de inconformidade com a situação de Portugal na época, transparecendo o sentimento de indignação e revolta que o povo experimentava.

Então, no âmbito da literatura, o pós-74 configura-se como um momento que inaugura novas formas de ver e pensar Portugal. Saramago segue essa linha compósita, trazendo ao debate, como fizeram diversos autores portugueses da época, o peso que a tradição portuguesa carrega, estando ligada, ainda, a um passado glorioso. Além de seus romances metaficcionais, uma obra em especial integra tal problemática, sua coletânea de contos Objecto quase (1978), que propõe pensar o homem em um estado de quase objeto, situação induzida pela opressão totalitária que o conduz a um estado de submissão inconsciente.

Contaminado pela sensibilização oriunda do processo de silenciamento social e cultural promovido pelo governo ditatorial, e pela insistência na conservação de um passado tradicional pautado em mitos, Saramago se posta à tarefa de recontar e relativizar dados da história recente e tradicional de Portugal, em um movimento que traz para discussão a permanência de um dado passado na perspectiva do presente, pois ao passo em que discute de maneira vivenciada e problematizada a questão do embargo sofrido pelo país durante o período ditatorial, o autor volta a um passado distante, quase mítico, em "Refluxo", para refletir sobre as decisões de um rei que não mede esforços, nem vidas, para cumprir seus desígnios. 
Percebemos em alguns dos contos da coletânea a presença de um governante autoritário, que não leva em consideração a vontade de seu povo. $\mathrm{O}$ primeiro conto, "Cadeira", em que esse governante tem sua queda proclamada, introduz a perspectiva da abordagem histórica da obra, no sentido de deflagrar o início do fim de uma era de opressão, que leva o homem a um estado de coisificação para a própria manutenção daquele sistema.

Apenas os três primeiros contos dialogam com a história de Portugal de uma maneira mais notória, porém, a temática da opressão se faz presente na quase totalidade das narrativas que compõem a coletânea, sob a perspectiva do homem de massa que se submete a esta e outras formas de controle. No caso do contexto contemporâneo essa crítica se faz, principalmente, no âmbito da configuração do homem de massa, que se percebe coisificado ao ponto de ser controlado pelos objetos, culminando em sua total objetificação e na humanização de tais objetos.

\section{2) O homem como um mecanismo}

Os dados de reflexão sobre a automatização da humanidade começam a ser problematizados já no segundo conto da coletânea: "Embargo". Nele, o narrador introduz as pistas para uma crítica à dissolução de valores humanísticos em troca do materialismo. A tensão, não só dos personagens, mas dos fatos narrados, é algo marcante no conto. E isso vem, além da temática fantástica, da escolha que Saramago faz pelo narrador onisciente neutro, que se interpõe entre o leitor e os fatos narrados, mantendo um posicionamento imparcial a respeito dos fatos que apresenta.

Essa tensão resulta na inquietude do leitor diante da narrativa, tanto pela sua precisão quanto pela passividade do narrador frente ao destino trágico do personagem. Esse narrador neutro mostra os fatos como se lhe fossem independentes. Associada à tensão, está a intensidade, que é marcante no conto. De acordo com Júlio Cortázar, a “intensidade num conto consiste na eliminação de todas as ideias ou situações intermédias, de todos os recheios ou fases de transição que o romance permite e mesmo exige." (CORTÁZAR, 2008, p. 157)

No conto de Saramago, é possível observar esse mesmo aspecto: não se perde tempo da narração, ao leitor não é dada nenhuma explicação de por que o carro perde total controle sobre si próprio e por que ele prende o motorista, personagem principal. Os fatos simplesmente são narrados com naturalidade, não sendo estranhos ao narrador, 
mas sim aos personagens e ao leitor. É eliminada, assim, e de uma forma diferente da referida por Rosenfeld (2015), a causalidade: o principal fato que acontece no conto - o carro ter domínio sobre si e sobre o motorista - não é decorrente de uma causa passível de explicação.

Entretanto, a questão do narrador de Saramago não pode ser pensada apenas nos limites das classificações teóricas e críticas existentes, pois ele suplanta qualquer ideia de relação entre leitor e narrador que tenhamos conhecido. O narrador saramaguiano opera na narrativa um papel preponderante, e mesmo quando se faz ausente, ou distanciado, ele quer nos dizer algo, e esse algo, na maioria das vezes, nos revela muito sobre nós e sobre a posição que ocupamos no mundo.

Partindo para uma análise mais detalhada do conto "Embargo", percebemos, em meio à sujeira e ao caos urbano, consequentes do embargo petrolífero, que a principal preocupação do protagonista é com o furto de gasolina de seu carro (SARAMAGO, 1994, p. 35), que denota a reação das pessoas frente a uma dificuldade gerada por um fator externo: voltar-se contra seus iguais no interior do grupo, praticando indiscriminadamente o egoísmo, que marca a apoteose da individualidade e a dissolução de qualquer indício de coletividade e de colaboração. Esse fator põe ainda mais peso sobre a questão da submissão do homem aos objetos e ao consumo. O homem demonstra um gosto e um zelo pelo carro, escolhendo com cuidado o local de estacionamento, verificando-lhe a integridade das partes e regozijando-se com seu desempenho. Essa satisfação se dissolve à medida que evolui a sua percepção e preocupação com a própria liberdade.

O contentamento do protagonista do conto marca o início da narrativa: "Ligou a ignição, e no mesmo instante o motor roncou alto, com um arfar profundo e impaciente. Sorriu, satisfeito da surpresa." (SARAMAGO, 1994, p. 35); "O carro estava melhor do que nunca. Respondia aos seus movimentos como se fosse um prolongamento do seu próprio corpo.” (p. 37) Nesse momento, a tomada de controle pelo carro ainda é aceita como positiva, causando-lhe admiração pelo desempenho da máquina. Só adiante começa a considerar os riscos da sua perda de controle: "Uma marcha atrás que funciona ora sim ora não, é um perigo.” (p. 38) E então, quando percebe sua completa perda de controle e incapacidade de desvencilhamento, passa a não mais apreciar a atitude do automóvel. Enquanto a sua submissão à máquina ainda lhe é confortável, não só não há incômodo, como há consentimento. No decorrer do conto, o narrador conduz 
os espaços da narrativa nesse sentido: do "casulo morno que era a cama" (p. 33) até o carro, que inicialmente tem um "calor agradável, como dos lençóis" (p. 36) e que finda como um "casulo quente e embaciado" (p. 43), estabelecendo uma relação de oposição entre o "morno" e o "quente" na construção dessa virada narrativa.

Outro elemento importante na seleção lexical do narrador é o fato de o carro ser, em quase todas as ações que lhe concernem, o sujeito da oração: "o automóvel arrancou" (p. 35), "o carro insinuou-se" (p. 36), "o carro deu uma guinada" (p. 36), “o automóvel subiu o passeio" (p. 37), "o carro, a vinte metros, obliquou para a esquerda, por si mesmo, e foi parar, suavemente, como se suspirasse, no fim da fila" (p. 38). Isso ocorre até o momento em que o homem se percebe definitivamente preso ao carro.

Opondo-se a isso, o personagem revela não ter um controle direto sobre o próprio corpo: "fez mover os músculos” (SARAMAGO, 1994, p. 36), no lugar de "moveu os músculos", como se delegasse ao próprio corpo a ação, e não a estivesse realizando ele mesmo. Nesse sentido, seu corpo parece algo desconectado de si, ou com uma conexão atravessada. Do mesmo modo, o narrador não diz que o homem "se sentiu perplexo", mas sim que "puxou o retrovisor e olhou-se no espelho. Viu que estava perplexo e considerou que tinha razão." (p. 38) O mesmo ocorre depois: "Puxou para baixo o retrovisor e olhou-se. Nenhuma diferença no rosto. Apenas uma aflição imprecisa que mal se dominava.” (p. 40) A construção da narrativa dá a entender que a mente do personagem parece não captar as emoções: seu corpo reage à aflição, sua expressão facial expressa essa sensação, e só então a mente do homem toma ciência do sentimento, apenas quando averigua sua imagem no espelho. Assim, o homem parece desconectado de suas emoções, restando-lhe apenas os sentidos, que usa para verificar o estado emocional do corpo.

A estranheza dessa construção pode conduzir a uma reflexão acerca do desligamento entre as pessoas e seus sentimentos, bem como da perda da compreensão sobre si mesmo, que é substituída pela ocupação constante da mente com um grande volume de informações, com a necessidade de produtividade, com o preenchimento de todo o tempo ora com o trabalho, ora com o consumo de bens e serviços, suplantando o simples e necessário ócio que poderia permitir um estar consigo, um conhecer de si mesmo. Além disso, é válido observar que o que permite ao personagem perceber a expressão de seu rosto é a utilização de um equipamento - o espelho retrovisor - que faz parte do carro. Ou seja, ele averigua seu estado de espírito através do carro, o que 
sublinha a simbiose operada pelo narrador. Desse processo advém a ideia de que o humano se submete aos objetos, ao consumo e, consequentemente, ao sistema, tornando-se seu ator, sua ferramenta, além de sua vítima.

O enleio do corpo humano com o animal ou com os objetos é uma questão existente em outros contos de Objecto quase: "Cadeira" e "Coisas" têm esse aspecto patente. Porém, é em "Embargo" que essa ligação se associa a uma forma de dominação do humano pelo contato. Nele, é formado um ciborgue, um corpo humano fundido ao maquinário, e este passa a dominar aquele. Essa fusão encontra ligação também com o conto "Centauro", visto que o carro, que se funde ao corpo do homem, é referido constantemente como um animal e, ao final, assim como a figura mitológica clássica, é apartado do corpo humano. Entretanto, é na fusão homem-carro que se encontra uma relação de submissão do humano. Em “Coisas” essa mesma submissão se observa, mas o protagonista tem muito gosto em servir o sistema, sustentando-o voluntária e conscientemente, enquanto o homem de "Embargo" passa por um processo que vai de uma inconsciência do controle até sua percepção, na progressão de uma inquietude que evolui até o desespero. No início, é compassivo com os movimentos independentes do carro, pois ainda era agradável estar em seu interior morno e tranquilo. Sua ideia só muda quando ele passa a identificar perigo na insurgência do automóvel, sobretudo após a percepção de que se encontrava irremediavelmente enclausurado a este espaço, que passa a ser tempestuoso pela entrada do vento, da chuva e do frio.

Assim, o personagem de "Embargo" tem tempo de perceber sua condição de dominado e de tentar se desvencilhar. Sua colaboração se extingue antes que a coisa que o oprime seja vencida pela extinção daquilo que a alimenta: o dinheiro do ser dominado. Tudo isso dentro de um contexto de embargo externo, como se o autor produzisse uma analogia a respeito desse personagem e seu automóvel a um povo dominado por um Estado que lhe oprime e se alimenta de sua riqueza, apenas podendo ser confrontado pela combinação de uma repressão externa com a própria ruína do ser oprimido. Só então o ente dominador finalmente arrefece e suspende o seu domínio.

\section{3) Os homens contra as coisas}

O cenário de "Coisas" já é bastante diferente, pois em "Embargo" a atmosfera é de embate, de atrito entre homem e máquina, enquanto no primeiro esta batalha já se encontra vencida pelas máquinas. Vislumbramos na narrativa, através do uso do 
fantástico, a apoteose da sujeição humana representada em vários sentidos, marcada pela despersonalização dos personagens, submetidos à nomenclatura da função e da importância que exercem em sua sociedade, assim como de classe social. Tais personagens não possuem nomes, e por vezes são referidos como "utentes", termo que dialoga com a ideia de utensílio, deflagrando a iminência da necessidade da utilidade das coisas e das pessoas para que haja sentido em sua existência, ao passo que os objetos são ironicamente denominados "oumis", que por sua vez é uma espécie de trocadilho com a palavra "homem". Assim, o "funcionário" irá nos levar de modo quase automático (o que dialoga com a abordagem temática da narrativa), através do narrador onisciente seletivo, que nos apresenta os fatos através de um único ponto de vista, o seu, que percebe o mundo ficcional por meio de uma perspectiva marcadamente utilitária.

A configuração social da narrativa demonstra de forma extremada um modo de vida bastante semelhante ao que vivenciamos contemporaneamente, marcado pela indiferença ao sofrimento do outro, pois humanamente, "a modernidade construiu uma subjetividade desengajada e com indivíduos cada vez mais solitários e indiferentes à dor do outro". (BAUMAN, 2003, p. 171). O personagem principal de "Coisas",

vivia sozinho e solteiro. Fazia a sua própria comida, mandava lavar fora a roupa, gostava do emprego. De um modo geral, considerava-se um homem satisfeito. Difícil era não o ser: o país excelentemente administrado, as funções bem repartidas, o governo capaz e com grande experiência de transformação industrial. (SARAMAGO, 1994, p. 76)

Sua vida, a exemplo dos demais sujeitos da narrativa, segue uma sequência cotidiana rígida, onde não cabem reflexões sobre a felicidade ou as relações, apenas sobre sua existência mecanizada, esvaziada. E, quando ocorre alguma falha nesse universo, que rompe com a normalidade inventada e naturalizada, o sentimento é de inquietude, de medo, pois esses sujeitos estão acostumados a outorgar sua existência a um tipo moderno de Deus burocratizado e tecnológico. É o que ocorre quando o funcionário percebe sua rotina e seu conforto comprometidos:

A regularidade do seu quotidiano fora afectada pelos acontecimentos [...] Em geral, tinha tempo de ler o jornal todo, preparar um jantar simples e instalar-se em frente do televisor, a ouvir as notícias e a comer. [...] Estendeu a mão e ligou o aparelho: ouviu um silvo, o mostrador foi-se iluminando aos poucos até aparecer a mira de afinação, um complicado sistema de riscos verticais, horizontais e oblíquos, de superfícies claras e escuras. [...] Um estalido forte fê-lo 
voltar a cabeça rapidamente. «Algum móvel», pensou. E nesse exacto instante, por um lapso de tempo inferior a um segundo, a mira desapareceu e no seu lugar, como um relâmpago, surgiu a cara duma criança, com os olhos muito abertos. Sumiu-se para o fundo, para trás, para longe, muito longe, até se transformar num simples ponto luminoso, palpitante, no centro do mostrador negro. Logo a seguir reapareceu a mira de afinação, ligeiramente trêmula, ondulante, como uma imagem reflectida na água. O funcionário passou a mão pela cara, perplexo. Pegou no telefone, ligou para os serviços de informações da televisão (sitv) e, quando de lá atenderam, perguntou: — Faz favor. Que interferência foi esta que apareceu agora mesmo na mira de afinação?

Uma voz de homem respondeu, secamente: - Não houve qualquer interferência. (SARAMAGO, 1994, p. 77)

O funcionário é o típico sujeito moderno, isolado, desenraizado, sem capacidade política, é um homem esvaziado, que marca um estado de alienação, em que sua vida social é devorada, enquanto sua vida privada e sua vida política são estreitadas, ao ponto de se

apagar todo espaço político. O homem da modernidade conhece, assim, o isolamento, que é o impasse para o qual são conduzidos os homens, a partir do momento em que a esfera política de sua vida comum é destruída. Soma-se a isso o desenraizamento, que cria a desagregação das relações humanas. (SOUKI, 2006, p. 95)

Paralelo à inquietação da população em consequência dos eventos que estão acontecendo fora da ideia de normalidade que apresentava, o governo (g) começa a demonstrar também traços de fraqueza, ao passo que procura manter o controle dos cidadãos utentes, que "devem recusar o boato, o empolamento, a manipulação. Devem manter a serenidade, mesmo no caso de ocorrerem desaparecimentos dos ditos oumis" (SARAMAGO, 1994, p. 78). Além disso, solicita a ajuda dos utentes na manutenção do controle da situação, deflagrando assim sua incapacidade de controlar as consequências daquele fenômeno. Em troca dessa ajuda, o governo está disposto a romper com as regras de ascensão social estabelecidas naquele espaço, que antes era gerido principalmente pela descendência e pelo poder aquisitivo, o que significa dizer que o lugar que o cidadão ocupava naquela estrutura social era determinado por fatores que não poderiam ser controlados por eles, apenas pelos detentores do poder, mas: agora "o cidadão utente que der informações completas ou detiver o processo de desaparecimento de oumis, será considerado benemérito e promovido à precedência $\mathrm{C}$, se estiver classificado em precedência mais baixa". (SARAMAGO, 1994, p. 78) 
Entretanto, nenhuma ação do governo foi capaz de controlar o desaparecimento dos objetos (oumis).

A manutenção de uma suposta normalidade se mostra um fator necessário para que a situação se estabilize e para que as pessoas não passem a questionar a estrutura social à qual estavam subjugados. O sentido de "normal" aqui adotado é o que se entende como de acordo com uma norma, e "anormal", fora do modelo estabelecido. Vale aprofundar este sentido com o que discute Foucault em Segurança, território, população (2008) [1978]:

A normalização disciplinar consiste em primeiro colocar um modelo, um modelo ótimo que é construído em função de certo resultado, e a operação de normalização disciplinar consiste em procurar tomar as pessoas, os gestos, os atos, conformes a esse modelo, sendo normal precisamente quem é capaz de se conformar a essa norma e o anormal quem não é capaz. Em outros termos, o que é fundamental e primeiro na normalização disciplinar não é o normal e o anormal, é a norma. (FOUCAULT, 2008, p. 76)

Esse entendimento corrobora com o que o autor discute em A microfísica do poder (2001) [1978], em que diz que "A prática do internamento, no começo do século XIX, coincidiu com o momento em que a loucura é percebida menos com relação ao erro do que com relação à conduta regular e normal” (FOUCAULT, 2001, p. 69), e mais à frente acrescenta que "no início das sociedades industriais, instaurou-se um aparelho punitivo, um dispositivo de seleção entre os normais e os anormais" (p. 85).

Há, no sentido que Foucault dá às palavras normal e anormal, como se pode perceber, o estabelecimento de condutas aceitas e não aceitas. O que se destaca é a ideia de que a normalização está ligada a uma disciplinarização. A normalização é, nesse sentido, o estabelecimento de normas que de alguma maneira orientam o andamento de uma sociedade ou de um povo.

E o que se vê no conto "Coisas", e em outros contos de Objecto quase, é justamente o rompimento das normas (naturais ou instituídas) decorrente da impossibilidade de os personagens, à primeira vista, dizer o que é normal e que não é. Neste conto, novas regras ou normas são estabelecidas a fim de que permaneça o estado habitual de diferenciação entre homens e objetos. Como diz Victor, o interlocutor de Foucault na seção "Sobre a justiça popular" de A microfísica do poder, parece ser necessário a existência de uma "instância de normalização" (2001, p. 27). E o que se busca no conto é a manutenção da organização social através de um sistema de normas, ainda que seja preciso alterá-las e renová-las. 
A abordagem desta temática por via do fantástico não é inoportuna, pois nos induz, através da naturalização da anormalidade, à imersão em um universo distópico que deflagra o fim do caminho que estamos trilhando enquanto humanidade, e que não promete ser favorável, mas que tem bastante semelhança com o mundo real. Ao problematizar tais questões no sentido distópico, os textos de Saramago dialogam com a ideia de que

as distopias problematizam os danos prováveis caso determinadas tendências do presente vençam. É por isso que elas enfatizam os processos de indiferenciação subjetiva, massificação cultural, vigilância total dos indivíduos, controle da subjetividade a partir de dispositivos de saber etc. (HILÁRIO, 2013, p. 206)

A distopia, portanto, possui um traço de crítica do presente no sentido de refletir sobre a realidade e suas possibilidades. Esse dado se afasta da relação comumente estabelecida entre distopia e ficção científica, pois ela não se limita apenas a projetar a temática futurista, ela funciona também como ferramenta para combater o presente na tentativa de evitar determinado futuro, faz "soar o alarme que consiste em avisar que se as forças opressoras que compõem o presente continuarem vencendo, nosso futuro se direcionará a catástrofe e barbárie". (HILÁRIO, 2013, p. 207)

A narrativa "Coisas", de Saramago, assim como as temáticas gerais dos contos de Objecto quase, deflagra um dado da sociedade contemporânea que leva seus indivíduos a um colapso social, oportunizado pela perda de sua subjetividade, que na compreensão de Foucault favorece a composição de um "sujeito cujos méritos são identificados de maneira analítica, de um sujeito que é sujeitado em redes contínuas de obediência, de um sujeito que é subjetivado pela extração de verdade que lhe é imposta" (FOUCAULT, 2008, p. 243). A obra demonstra, assim, que os universos culturais criados pelo homem para significar sua existência e convivência, modulados por um princípio capitalista, suplantaram o próprio homem, que passou de opositor dos sistemas de controle social a mantenedor desse sistema, que o oprime e marginaliza, imerso em um estado de alienação.

Os sujeitos dessas e de outras narrativas de Saramago não produzem mais cultura, são produzidos por ela, são determinados pelos padrões sociais estabelecidos através do lugar que ocupam nessa sociedade. Exemplo disso é a escolha do autor em não batizar os personagens com nomes próprios, mas sim denominá-los de acordo com as profissões e funções que exercem na sociedade ficcional que habitam, contribuindo 
assim para a perda total de sua identidade. As subjetividades, portanto, são produzidas de acordo com o projeto político daquele contexto social, que cria seres úteis à manutenção do capitalismo, destituídos de sentimentos, de coletividade, de empatia, conforme pontua Foucault:

\begin{abstract}
O homem ocidental é individualizado através do pastorado, na medida em que o pastorado leva à salvação que fixa sua identidade por toda a eternidade, em que o pastorado o sujeita a uma rede de obediências incondicional[ais], em que ele lhe inculca a verdade de um dogma no momento mesmo em que lhe extorque o segredo da sua verdade interior. Identidade, sujeição, interioridade: a individualização do homem ocidental durante o longo milênio do pastorado cristão foi realizada à custa de subjetividade. (FOUCAULT, 2008, p. 310)
\end{abstract}

A ideia de pastorado discutida por Foucault pode ser localizada recorrentemente na narrativa "Coisas", levando a discussão, através da ironia, o estado de alienação do homem, e de que forma ele naturaliza o controle do poder sobre si. Entretanto, o autor faz essa abordagem por meio do fantástico, o que acaba por revelar o quão absurdo é aquilo que a modernidade produziu e normalizou. Assim, ao selecionar essa abordagem distópica aliada à presença do fantástico, o autor fixa um outro tipo de contrato de leitura com o receptor do texto, pautado não apenas no que foi, mas principalmente no que poderá ser, em função de a leitura fantástica se pautar

na confrontação do sobrenatural e do real dentro de um mundo
ordenado e estável como pretende ser o nosso, a narrativa fantástica
provoca - e, portanto, reflete - a incerteza na percepção da realidade e
do próprio eu; a existência do impossível, de uma realidade diferente
da nossa, leva-nos, por um lado, a duvidar desta última e causa, por
outro, em direta relação com isso, a dúvida sobre nossa própria
existência, o irreal passa a ser concebido como real, e o real, como
possível irrealidade. Assim, a literatura fantástica nos revela a falta de
validade absoluta do racional e a possibilidade da existência, debaixo
dessa realidade estável e delimitada pela razão na qual vivemos, de
uma realidade diferente e incompreensível, alheia, portanto, a essa
lógica racional que garante nossa segurança e nossa tranquilidade.
(ROAS, 2014, p. 32)

O fato de os contos "Coisas" e "Embargo" lidarem com um assunto tão em voga na atualidade, que é o problema do domínio cada vez mais acelerado da tecnologia sobre o homem, conecta o leitor à possibilidade de vislumbrar as consequências desse crescimento incontrolável, não no sentido de apenas expor um elemento sobrenatural marcado como evasão, e sim como forma de questioná-lo, fazendo com que percamos 
nossa segurança diante do mundo real. Portanto, "o sobrenatural vai supor sempre uma ameaça à nossa realidade, que até esse momento acreditávamos governada por leis rigorosas e imutáveis". (ROAS, 2014, p. 31) Na perspectiva de que

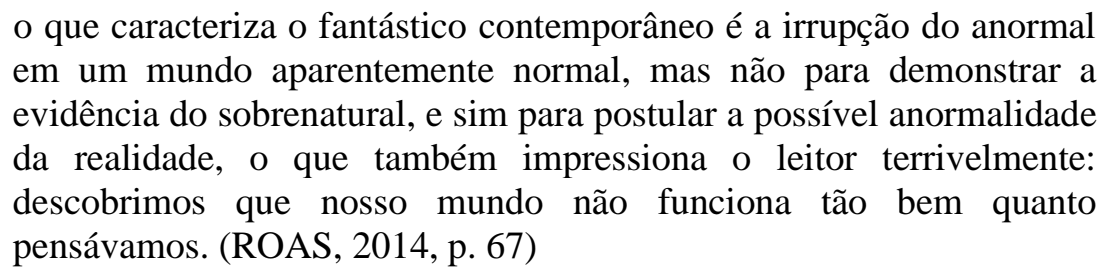

Este fator está disposto de maneira bastante intrigante em Objecto quase, que parece nos levar a pensar sobre uma situação de sujeição a partir de suas origens, que são oportunamente totalitárias, e o perigo vislumbrado pela sua manutenção, que é a incapacidade de pensar do homem, de se reconhecer objeto e de transcender essa sujeição a partir mesmo do retorno ao pensamento, concomitante ao reconhecimento de sua condição. Desse modo, conforme argumenta Foucault sobre o controle que o discurso de poder exerce, esse discurso precisa ser legitimado não só por aqueles que operam a opressão, mas também "necessita da agência dos indivíduos para poder ser efetivo". (BONNICI, 2009, p. 257).

De uma maneira geral, a perspectiva de Foucault entende que os discursos funcionam "independente das intenções específicas individuais", uma vez que "se perpetuam pelos usuários que reproduzem seu poder". Assim, "o discurso é internalizado por nós, organizando o nosso ponto de vista do mundo e colocando-nos como um elo (inconsciente) na cadeia do poder". (BONNICI, 2009, p. 259) Percebemos isso de uma maneira muito clara na narrativa de "Coisas", pois seu personagem principal, denominado não aleatoriamente como "funcionário", reproduz a ideia de legitimação de uma estrutura de poder por meio de sua resignação a ela. Para ele, não há outra forma de existência longe dos parâmetros daquela conjuntura opressiva. Porém, o personagem não a reconhece sob esse ponto de vista, o que o incapacita de exercer a competência de pensar. Para Souki, na leitura que faz do pensamento de Hannah Arendt, o homem que nasce desse conflito é o "homem de massa", que

atua sob ordens, que obedece cegamente e é incapaz de pensar por si mesmo, pois essa supremacia da obediência pressupõe a abolição da espontaneidade do pensamento. E nessa ausência de pensamento, nessa expressão humana opaca, nessa rarefação das consciências que aparece a tragédia, batizada por Hannah Arendt de a "banalidade do mal". (SOUKI, 2006, p. 11) 
Para o funcionário, aquela é a única forma capaz de gerir a existência dos homens, e nem mesmo quando a crise se intensifica e o caos começa a operar indiscriminadamente ele perde a fé no governo, que "estaria decerto a estudar o assunto. Houvera outros casos antes, embora menos graves, e sempre se achara solução. Nada de desesperos. A boa ordem voltaria à cidade. Uma crise, uma simples crise, e nada mais". (SARAMAGO, 1994, p. 97) Este homem sintetiza perfeitamente o "homem de massa", que tem como principal característica

o isolamento e a falta de relações sociais normais. O totalitarismo, apoiando-se em uma massa atomizada, procura torná-la sempre mais atomizada e amorfa; massa de indivíduos isolados, anônimos, sem interesses pessoais, sem poder, pois homens isolados sem interesses em comum não têm nenhum poder. Nesse contexto, o senso comum é uma categoria capital para a reflexão sobre o fato político, porque ele é, precisamente, o contrário do isolamento que age sobre a via da aniquilação da esfera política. Aqui o senso comum se caracteriza como o sentido do real, condicionando o indivíduo a se relacionar com a realidade do mundo em que vive, a dominá-la, julgá-la, a se adaptar, a modificá-la, enfim, de ser ele. Assim, a dominação totalitária passa pela destruição desse sentido da realidade, dessa faculdade que se apoia na presença do outro. (SOUKI, 2006, p. 122)

Durante toda a narrativa, o funcionário vaga sozinho, não demonstra nenhum sentimento com relação às outras pessoas que vivenciam aquela mesma situação, pelo contrário, é apático, indiferente a qualquer sensibilização sobre o outro, assim como toda a população. No momento em que a distinção entre homens e objetos se torna impossível para o governo, uma medida emergencial é tomada:

O governo $(\mathrm{g})$ registra e agradece a colaboração dada por muitos cidadãos, mas lembra que os benefícios da vigilância, resultantes da presença em massa nas ruas e praças, acabam por ser prejudicados por essa mesma massa. É preciso isolar o inimigo, e não proporcionar-lhe condições para se ocultar. Atenção, portanto. $\mathrm{O}$ nosso tradicional costume de mostrar as palmas das mãos deve tornar-se, a partir deste momento, lei e dever. [...] A palavra de ordem na situação actual é a seguinte: vigilância e mão aberta! [...] Nasceu assim, ao mesmo tempo por toda a cidade, a prática mais imediata e rápida de reconhecimento e identificação: as pessoas não precisavam de parar, passavam umas pelas outras, de braço estendido, dobrando a mão pelo pulso, para cima, e exibindo a palma marcada com a letra da precedência. Era fatigante, mas poupava tempo. (SARAMAGO, 1994, p. 87-88) 
Essa medida constrói uma imagem bastante forte e representativa daqueles sujeitos. Aqui eles são levados por movimentos automáticos para distinguir-se dos objetos, entretanto, a impressão que temos é que talvez eles estejam mais esvaziados de humanização do que os próprios oumis: “As pessoas arrastavam-se pelas ruas, estendiam o braço, continuavam, cada vez mais cansadas, sem saber para onde ir e onde parar". (SARAMAGO, 1994, p. 89)

Outro elemento que projeta essa dimensão é a composição da gerência institucional de toda a vivência dos sujeitos, o que marca o ambiente e as relações da narrativa: o fato de que tudo é extremamente burocratizado, não há nada que os indivíduos daquele lugar façam ou pensem sem que o governo esteja ciente, conforme assevera Siqueira:

instituições, setores, serviços, funções ou ações oficiais são identificados por uma sigla específica, denotando tanto o excesso de burocracia, quanto a perda de significados das palavras no sistema de padronização de ações e da linguagem cotidiana: serviço médico (sm), serviço de requisições oficiais (ser) - onde trabalha o funcionário, governo (g), serviços de abastecimentos correntes (sac), nog (nota do governo). (SIQUEIRA, 2018, p. 116)

Isto limita, inclusive, suas ações, demonstrando um comportamento completamente passivo, se limitando apenas a observar, em dados momentos, que algo foge à rotina, mas não há reflexão sobre tais questões. Um exemplo que pode ser mencionado é quando a instabilidade do comportamento dos objetos toma proporções maiores: "- Tem havido bastantes casos estranhos nestas últimas semanas. - O governo está atento e vai com certeza providenciar.” (SARAMAGO, 1994, p. 70) A solução está sempre nas mãos do Estado, ao cidadão cabe apenas o auxiliar, mesmo que seja não interferindo. Este cidadão obediente age sem refletir sobre as implicações de suas atitudes, repetindo que "é preciso ajudar o governo (g)". (SARAMAGO, 1994, p. 85)

Contrário a isso está o funcionário da cafeteria, que ao ser questionado pelo protagonista a respeito de sua opinião sobre os fatos decorrentes na narrativa, o surpreende, ao deflagrar um discurso que se contrapõe ao poder operante, revelando sinais de rompimento, em suas palavras: "Olhe, se quer que lhe diga. Tanto se me dá. Até acho divertido." (SARAMAGO, 1994, p. 86) Entretanto, essa atitude não passa despercebida pelo controle ditatorial, e o sujeito sofre as consequências pela impertinência de pensar quando lhe é negado esse direito. Após a saída do funcionário da cafeteria, "quinze minutos depois, um automóvel escuro parou em frente ao café. 
Dois homens armados saíram do carro e entraram no estabelecimento. Daí a pouco tornaram a aparecer, trazendo o criado algemado" (SARAMAGO, 1994, p. 86). Essa situação deflagra outra característica do controle do poder, a de que "os indivíduos que pensam ou falam fora dos parâmetros do discurso dominante são definidos como loucos ou reduzidos ao emudecimento" (BONNICI, 2009, p. 258).

Para o poder operante é crucial a manutenção do estado de alienação dos sujeitos, pois seria nociva sua conscientização, sua compreensão e reflexão sobre o discurso de poder que opera sobre eles, pois "ao ser exposto, o discurso torna-se frágil e fica mais propenso a ser contrariado" (BONNICI, 2009, p. 259). É o que ocorre no conto "Coisas", com a insistência do governo em manter a ordem e incutir a ideia de normalidade e controle da situação. Além disso, a fé dos utentes no governo se mantém, mesmo nas circunstâncias mais adversas, o que se demonstra na fala do personagem principal, ao ser questionado sobre o retorno da normalidade: "a situação continuaria a agravar-se durante algum tempo, mas que não tardaria a normalizar-se. Depois entrarse-ia em recuperação.” (SARAMAGO, 1994, p. 80)

Ao passo em que a narrativa se desenvolve, os dados inquietantes que rompem com a normalidade da existência dos personagens ganham proporções maiores, ao ponto de os objetos começarem a sumir, e não apenas se rebelar, como no caso do marco postal que desaparecera. Esse "procedimento parte de uma situação aparentemente natural, mas que gradativamente caminha para o estranhamento, por meio de ocorrências inusitadas e insólitas, desenvolvendo-se em um processo ascendente a partir do primeiro acontecimento narrado" (SIQUEIRA, 2018, p. 116). Após o sumiço, o funcionário "aproximou-se do local onde [o marco] deveria estar, onde há tantos anos o via, com aquele corpo cilíndrico pintado de azul e a fenda rectangular, boca permanentemente aberta, muda, só entrada para um estômago" (SARAMAGO, 1994, p. 73). O narrador descreve os objetos sempre de forma humanizada, e isso se demonstrará bastante representativo no desfecho da narrativa.

Este conto, em especial, apesar de ambientar-se no universo do fantástico, tem muito a nos dizer sobre a realidade, principalmente sobre aquela vivenciada pela população portuguesa no período ditatorial. A forma escolhida pelo autor para a linguagem do conto nos coloca diante de uma realidade aterrorizante, exatamente porque sua ambientação, o mundo que constrói enquanto linguagem, dialoga com nossa realidade. Esse dado da literatura fantástica "põe em manifesto as relações 
problemáticas que se estabelecem entre a linguagem e a realidade, pois tenta representar o impossível, ou seja, tenta ir além da linguagem para transcender a realidade admitida." (ROAS, 2014, p. 58). Mas esse impossível narrado pelo conto se aproxima tanto de nós, que seu efeito sobre a realidade cotidiana, oriunda do atrito entre o real e o hiperimaginado "nos obriga a questionar se o que acreditamos ser pura imaginação pode chegar a ser verdade, o que nos leva a duvidar de nossa realidade e do nosso eu, e diante disso não resta nenhuma outra reação a não ser medo" (ROAS, 2014, p. 61).

O que é mais devastador na narrativa é o sentimento de inquietude do funcionário, que se desenvolve e que nos faz ter esperança em sua redenção. Porém, o que ele quer, no fim das contas, é apenas o retorno da normalidade, a volta do controle absoluto, ele é movido por um desejo de poder pautado no individualismo, pois não pensa no bem comum, seu único desejo é ocupar o lugar do opressor naquela estrutura social:

Em baixo, a multidão era cada vez maior. Entre a artilharia e o limite da cidade instalava-se agora uma fila de metralhadoras pesadas. Ai dos oumis que viessem para este lado. O funcionário sorriu: o castigo seria exemplar. Lamentou não estar no exército. Gostaria de sentir nos pulsos, mesmo na sua mão ferida, que importava isso, o vibrar da arma causado pelos disparos, o tremor de todo o corpo, que não seria então de medo, mas de furor e alegria justiceira. (SARAMAGO, 1994, p. 101)

Mas o desfecho do conto não ocorre como esperado, pelo menos por parte do funcionário, que nem mesmo pode assistir ao fim da grande ação militar, uma vez que "sentiu as mãos do homem em volta do pescoço, e as mãos da mulher sobre a boca, apertando" e "tivera tempo de ver que as mãos que o iam matar não tinham qualquer letra" (SARAMAGO, 1994, p. 102). E no momento final da narrativa, uma reviravolta surpreende o leitor mais uma vez, pois

Nenhum tiro chegou a ser disparado. No preciso instante em que o oficial ia gritar: «Fogo!», o microfone fugiu-lhe as mãos. Inexplicavelmente, os aviões fizeram uma curva apertada e voltaram para trás. Este foi apenas o primeiro sinal. Um silêncio absoluto espalmou-se sobre a planície. E de repente a cidade desapareceu. No lugar dela, a perder de vista, surgiu uma outra multidão de mulheres e homens, nus, desentranhados do que fora a cidade. Desapareçam as peças de artilharia e todas as outras armas, e os militares ficaram nus, rodeados pelos homens e pelas mulheres que antes tinham sido roupas e armas. Ao centro, a imensa nódoa escura da população da cidade. Mas também essa, no instante seguinte, se metamorfoseou e multiplicou. (SARAMAGO, 1994, p. 103) 
A partir do momento em que já não era possível distinguir homem de coisa, são as coisas que se rebelam, transformando-se, por sua vez, em humanos livres. A parte final da narrativa nos leva a pensar em uma completa integração entre homem e coisas, na perspectiva de que as coisas passam a fazer parte do que o homem se torna. A partir do reconhecimento do surgimento desse terceiro ser, é posta a ideia de um novo começo, pautado na libertação da necessidade, utilidade e domínio das coisas: “- Agora é preciso reconstruir tudo. E uma mulher disse: - Não tínhamos outro remédio, quando as coisas éramos nós. Não voltarão os homens a ser postos no lugar das coisas" (SARAMAGO, 1994, p. 103).

\section{4) Considerações Finais}

Saramago, através das narrativas dispostas em seu Objecto quase, nos leva à reflexão sobre questões da existência humana, sob uma perspectiva das relações de poder que regem a contemporaneidade, e que deflagram de que forma esses regimes se consolidam sob o discurso do homem desta época, marcado pela individualidade e sujeição. Ao introduzir o fantástico, sob a perspectiva de que ele "narra acontecimentos que ultrapassam nosso quadro de referência; é, portanto, a expressão do inominável" (ROAS, 2014, p. 57), para discutir as questões que propõe, o autor leva o leitor a uma projeção apocalíptica das consequências de suas escolhas.

Por fim, encerra as narrativas com "Desforra", que traz em seu título a ideia de reparação, como que para reparar o tom extremamente pessimista que as reflexões da coletânea traz, no sentido da desforra do homem para com o mundo contemporâneo, uma vez que o personagem principal abre mão dessa vivência para se dedicar a uma vida quase idílica, marcada pela simplicidade. Assim, ele passa de universos distópicos para um utópico, na projeção de afirmar uma possível salvação do homem, em que será necessário se pautar em uma profunda reflexão sobre si e sobre sua relação com mundo.

A desumanização constitui um fator central em Objecto quase, seja através do processo de objetificação do homem, como em "Cadeira", "Embargo" e "Coisas"; seja por sua animalização, como em "Centauro"; ou ainda pela tentativa de afastamento da morte em "Refluxo". Quando o homem tenta isolar a morte, está afastando de si um elemento essencial dos seres vivos e, assim, aproximando-se da máquina, que não morre. De acordo com André Lira (2012, p. 59), “o vivo, para se fazer vivo, morre 
permanentemente, e o dito morto, acolhido no reino da escuridão, para se fazer morto, vive permanentemente". Assim, esse afastamento da morte representa também um elemento de desumanização que caracteriza a tendência geral da coletânea, que desenha a humanidade, em diversas ocasiões insólitas, exposta ao domínio das coisas, relegada à condição de quase objetos.

\section{Referências}

BAUMAN, Zygmunt. Modernidade líquida. Rio de Janeiro: Zahar Editores, 2003.

BONNICI, Thomas. Teoria e crítica pós-colonialistas. In: BONNICI, Thomas; ZOLIN, Lúcia Ozana. (org.). Teoria literária: abordagens históricas e tendências contemporâneas. 3. ed. Maringá: Eduem, 2009.

CORTÁZAR, Julio. Valise de cronópio. São Paulo: Perspectiva, 2008.

FOUCAULT, Michel. Microfísica do poder. 16. ed. Rio de Janeiro: Graal, 2001 [1978].

FOUCAULT, Michel. Segurança, território, população. São Paulo: Martins Fontes, 2008.

GOMES, Álvaro Cardoso. A voz itinerante: ensaio sobre o romance português contemporâneo. São Paulo: Edusp, 1993.

HILÁRIO, Leomir Cardoso. Teoria crítica e literatura: a distopia como ferramenta de análise radical da modernidade. Revista Anuários de Literatura, Florianópolis, v. 18, $\mathrm{n}^{\mathrm{o}} 2$, p. 201-215, 2013.

LIRA, André. Poética e morte na era do ciborgue. Rio de Janeiro: Tempo brasileiro, 2012.

ROAS, David. A ameaça do fantástico: aproximações teóricas. 1. ed. São Paulo: Editora Unesp, 2014.

ROSENFELD, Anatol. Reflexões sobre o romance moderno. In: Texto/contexto I. São Paulo: Perspectiva, 2015.

SARAMAGO, José. Objecto quase. São Paulo: Companhia das Letras, 1994.

SIQUEIRA, Ana Marcia Alves. A linguagem fantástica em "Coisas" - a rebelião necessária. In: Revista do NEPA/UFF, Niterói, v.10, nº 20, p. 109-125, jan./jun. 2018.

SOUKI, Nádia. Hannah Arendt e a banalidade do mal. Belo Horizonte: Editora UFMG, 2006. 


\title{
LA RÉIFICATION DE L'HUMAIN CHEZ OBJECTO QUASE, DE JOSÉ SARAMAGO
}

\begin{abstract}
Sommaire
Cet article analyse des contes du livre Objecto quase, de José Saramago, spécialement "Embargo" et "Coisas", en soulignant la déshumanisation e la chosification des personnages. Ce processus dénonce l'un des mécanismes de domination typique de régimes totalitaires, la collaboration volontaire des dominés, en plus d'attirer l'attention sur le fort matérialisme des relations sociales à l'occident dès l'époque de publication de la collétaine (1978) jusqu'à aujourd'hui.
\end{abstract}

\section{Mots-clés}

Objecto quase. José Saramago. Narrateur. Réification. Deshumanisation. 